\title{
E-WOM Adoption and Sharing Behavior in Social Network Sites: The Impact of Engagement in SNSs
}

\author{
Jehad Imlawi ${ }^{1}$ \\ ${ }^{1}$ Information System Department, IT school, Al albayt University, Mafraq, Jordan \\ Correspondence: Jehad Imlawi, Information System Department, IT school, Al albayt University, Mafraq, Jordan.
}

Received: April 10, 2017

doi:10.5539/ibr.v10n6p87

\author{
Accepted: May 9, $2017 \quad$ Online Published: May 13, 2017 \\ URL: https://doi.org/10.5539/ibr.v10n6p87
}

\begin{abstract}
Social network sites (SNSs) is becoming a credible source of online information. Despite the increasing use of social networks in message persuasion literature, there is still a need for investigating the role it can play in users' adoption of online information and its impact on users' sharing behavioral intention of this online information. This research utilizes the peripheral route in elaboration likelihood model to investigate the impact of source credibility on engagement in SNSs and on e-WOM adoption, the impact of engagement in SNSs and recommendation rating on e-WOM adoption, and the impact of e-WOM adoption on sharing behavioral intention.

The findings suggest that factors, that are not directly related to the online message content, like source credibility, recommendation rating, and online users' engagement in SNSs groups, positively impact online information adoption by SNSs users, and their sharing behavioral intention of this online information. The study is finally concluded by suggesting the theoretical implications, and by providing strategies for firms to adjust their online activities in order to succeed in improving their customers' engagement, and their customers' adopting of these firms' products and services'information.
\end{abstract}

Keywords: E-WOM adoption, sharing behavioral intention, SNSS, engagement, source credibility, recommendation rating

\section{Introduction}

Previous studies show that word of mouth (WOM) communication, where customers exchange information about products and services, significantly affects decisions to adopt these shared information and experiences (Harrison-Walker, 2001). However, SNSs have transformed traditional WOM into electronic WOM (e-WOM). E-WOM defined as information (experiences and opinions) sharing via online platforms such as web sites, social networks, instant messages, news feeds, and other platforms (Lee \& Youn, 2009). Comparing to traditional WOM, e-WOM has the potential to be spread into a wider audience. E-WOM is considered more influential, because it attracts more interested customers.

E-WOM has changed the way online users behave before they make their decisions about online information adoption. Prior research has found that e-WOM can significantly affect customers' attitude toward online products and services (Li and Hitt, 2008; Che valier and Mayzlin, 2006; Cheung, Luo, Sia, and Chen, 2009; Park and Lee, 2008). Most travelers read online information about their travel experiences (Nielsen, 2008), especially that information published by other travelers who had similar travel experiences before.

SNSs have recently evolved to be one of the most important online sources for e-WOM. E-WOM has been published in many online resources like online reviews forums (Gretzel and Yoo, 2008), retailer websites (Fang, 2014), and SNSs, like Facebook and twitter. Customers perceive retailers as the least credible source of e-WOM, because of the conflict of interest. SNSs groups are expected to be more credible source when comparing to online reviews forums, because e-WOMs published in these forums does not usually go through any serious editorial process (Johnson and Kaye, 2002). Users need to be motivated to check these online reviews forums. While e-WOM published in SNSs are expected to be more accessible by everyone, even those who do not ask to see it. E-WOMs published by strangers in online reviews forums is not going to be perceived as credible as e-WOM information from their family or friends on SNSs groups (Luo et al., 2013).

The number of likes and comments received in SNSs is an indication for social recommendations (Lerman, 
2007). Researchers argued, when people believe in an idea, others would be motivated to support the same idea in a variety of contexts (Sundar and Nass, 2001). When a significant number of customers positively rate a product or a service, other customers' decision making process were found to be affected (Sundar, Oeldorf-Hirsch, and $\mathrm{Xu}, 2008$ ). In general, online information adoption by others considered a good reason for online users to adopt this information.

The main factor when studying SNSs use is engagement (Hassenzahl and Tractinsky, 2006). Prior research has found that in order to understand SNSs adoption, we should first understand users' engagement in these networks (imlawi, Gregg, and Karimi, 2015). Meaning that, understanding SNSs' adoption needs an understanding of SNSs' user's engagement in it (O'Brien and Toms, 2003). Engaging online customers has a significant impact on online sales, because online customers go to other online retailers when they are not engaged (O'Brien, 2008). However, more research is needed to study the role that engagement can play in SNSs. Specifically; antecedents of users' engagement in SNSs need to be investigated, because engagement is supposed to positively affect SNSs users' outcomes.

SNSs allow users to spread the word by sharing e-WOMs with a wide social capital. This allows online users to access online information about products and services they are interested in. This research adds to theory and practice by empirically examining antecedents of online information sharing behavior intention by SNSs users. Practitioners must be interested in results of this research, because sharing e-WOMs about their products with more online users is the ultimate measure that reflects users' believe in online information they get, and reflects users' adoption of online information.

This research investigates the impact of source credibility on engagement in SNSs and on e-WOM adoption, the impact of engagement in SNSs and recommendation rating on e-WOM adoption, and the impact of e-WOM adoption on sharing behavior intention.

\section{Theoretical Background and Hypothesis Building}

Prior research in online message persuasiveness and adoption has utilized Elaboration Likelihood Model (ELM) (Petty and Cacioppo, 1986). In brief, ELM assumes that the attitude toward any received information can be affected through two routes, the central route, and the peripheral route. The central route includes a high level of reader's elaboration, where a reader focuses more on the message information-relevant factors. The peripheral route, in the other side, involves a low level of reader's elaboration, where the reader is not highly motivated to consume high recognition efforts, and rather focuses more on information-irrelevant factors, like the information source credibility. The focus of this research is on the peripheral route, because it pertains factors related to the SNSs settings investigated in this research. These factors are: source credibility, recommendations rating, and SNSs users' engagement. Figure 1 shows the research model.

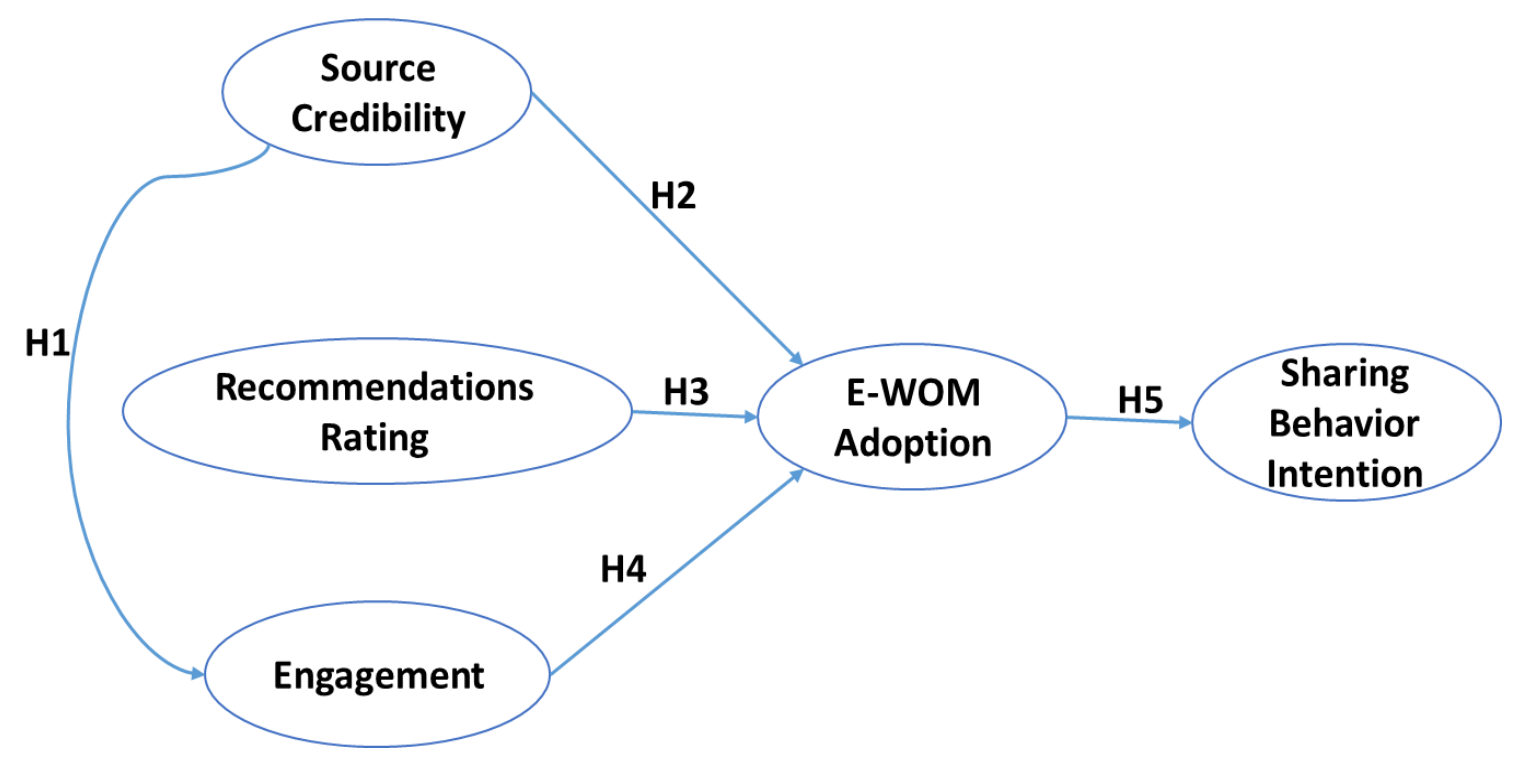

Figure 1. The research model 


\subsection{Source Credibility}

Source credibility was defined as a recipient's perception of the credibility of an information source, and is also a primary concern of SNSs users, when engaging in these networks (Pavlou and Dimoka, 2006).

SNSs groups that share e-WOMs are mainly affected by the source who shares these online messages. This source could be a close Facebook friend or a follower on Twitter. Consequently, the credibility of this information source may play a different role than it does in online review forums for example, where reviewers are mostly strangers.

Source credibility has been investigated by many IS studies in order to understand its effect on online information adoption and persuasiveness (Morimoto and La Ferle, 2008). Whether the message is online health information (Hu and Sundar, 2010), news stories (Xu, 2013), online travel recommendations (Ayeh, Au, Law, 2013), or brand attitudes in e-commerce (Chih, Wang, Hsu \& Huang, 2013); source credibility appears to have a significant impact on information influence and on persuasion (Sussman and Siegal, 2003). Source credibility is a necessary factor when selecting information (Xu, 2013), it determines whether users would believe the story and be engaged in it.

When readers receive any information, they try to evaluate the credibility of the information sources. Toward this target, they may rely on source expertise (Xu, 2013). Source expertise is one of the dimensions of source credibility (Rieh \& Danielson, 2007). Accordingly, information received from a source who's experienced in the field of this information, is expected to be more credible, engaging, adopted, and shared by the reader. The reader's trust in the message source is expected to be directly transferred to the message itself (Xu, 2013), which make it more engaging and more adopted by the reader. Source credibility would be a strong motivation for readers to select any information.

Uncertainty reduction theory suggests that individuals need to reduce uncertainty through understanding and learning (Berger and Calabrese, 1975). One of the strategies to reduce uncertainty is seeking credible sources of information before adopting it, or communicating with other individuals who share similar values (Tajfel and Turner, 1979). Accordingly, when SNSs members perceive online information source as highly credible, then this source would be more engaging for those members.

H1: E-WOM source credibility has a positive impact on SNSs group members' engagement in these groups.

H2: E-WOM source credibility has a positive impact on SNSs group members' adoption of information shared in these groups.

\subsection{Recommendations Rating}

Users on SNSs are expected to look at the value of e-WOM before they adopt it. If they find it worthy, they are going to adopt it, and share it with others. One of the most established ways of checking e-WOM value is by looking at its rating by others (Cheung, Luo, Sia, and Chen, 2009). E-WOM's rating on SNSs is an online resource that individuals can use to facilitate their decisions making process (Mudambi, and Schuff, 2010). Positive e-WOM rating by a considerable number of SNSs users, e.g. likes or comments on SNSs, is an indication of selecting and adopting the content of this e-WOM. This can also assist other SNSs users in evaluating and judging the credibility of the message, and adopting it as well.

According to ELM, when individuals do not have a motivation, or the ability to elaborate the content of the message, they depend on the peripheral route. In this case, instead of judging the mes sage content, individuals try to develop evaluation rules to help them evaluate the message content (Petty and Cacioppo, 1986). One of these rules is by looking at the recommendation rating, e.g. number of likes/comments left by SNSs users on the content of e-WOM. Number of SNSs likes and comments represents a social recommendation rating that motivates people to adopt this e-WOM. The reason for this motivation is because the idea that others are convinced by this e-WOM, and adopting it, is one of the rules that can assist in evaluating the e-WOM and adopting it. Meaning, when others believe something is right, I should do.

The impact of online social recommendation rating by a large number of SNSs users is expected to affect the receiver to adopt e-WOM, because it does in a number of similar fields. Online information about online books sales, for example, affected other buyers' purchase decisions. Travelers' online choices affected other travelers' choices. Brand ratings by customers affected other customers' decision making process (Sundar, Xu, and Oeldorf-Hirsch, 2009). In addition, music download information affected other's download intention (Salganik, Dodds, and Watts, 2006).

H3: Recommendations rating by SNSs group members has a positive impact on their adoption of e-WOM shared in these groups. 


\subsection{Engagement}

Engagement was defined as the feeling that a system has caught, captured, and captivated user interest (Jacques, Preece, and Carey, 1995). Engagement entails intrinsic interest. Therefore, research highlighted the importance of creating systems that are engaging, and motivating for users (Laurel, 1991; Malone and Lepper, 1987), and to study engagement factor as an important goal in the system design process (Mayes, 1992). Human-computer interaction research has recognized the need to develop experiences that engage users (Jacques et al., 1995; Hassenzahl \& Tractinsky, 2006).

According to the exchange theory, resource exchange can be achieved by personal interaction. E-WOM is an important resource in SNSs, and its adopting can be affected by recipient's engagement in online social networks. E-WOM is expected to be more adopted by recipients who are more engaged in the SNSs groups.

H4: SNSs group members' engagement in SNSs groups has a positive impact on their adoption of e-WOM shared in these groups.

\subsection{E-WOMAdoption}

One of the most important features that SNSs provide is sharing stories that users consider it useful with other users (Shoemaker, Johnson, Seo, and Wang; 2010). In SNSs, like Facebook, and Twitter, information sharing considered as one of the most valuable features.

Prior research suggests that news with more recommendations from others, and more adopted by others, would be shared more by SNSs users (Xu, 2013). Xu, (2013) found that information perceived by individuals as credible would be shared more extensively. This suggests that when SNSs users adopt any information, they would share it more with others. There would be no real value out of e-WOM content, if online users don't apply the communicated information, by adopting it in their decision making processes, and consequently, sharing it with others.

E-WOM sharing behavior is a response, by SNSs users, that reflects their acceptance and adoption of what the informant advocates (Cheung, and Thadani, 2012; Cheung, Luo, Sia, and Chen, 2009). E-WOM adoption is the most effective outcome of e-WOM communication, and is a meaningful measure of persuasion ( $\mathrm{Li}$ and Zhang, 2011). Information persuasiveness process involves a receiver's evaluation of information credibility (Wathen and Burkell, 2002). The positive outcome of this evaluation process is expected to improve the receiver's sharing behavior, because SNSs users, who perceive an e-WOM as credible, are expected to be interested in learning from it, and utilizing its content. Thus,

H5: SNSs group members' adoption of e-WOM shared in these groups has a positive impact on their sharing behavior intention

\section{Research Methodology}

A Web-based survey was used in this study. The first part of the survey described the study and its purposes. The second part of the survey is the main part; it includes the study measurement scales. The last part of the survey includes the "Thank you" page, and the participation confirmation code to get the extra credits.

\subsection{Participants}

A total of 260 undergraduate students, from a public uni versity in Jordan, participated in this study. They were required to have a Facebook account to be considered for participation. Participants considered for this study have reported some use of SNSs to share e-WOM about any products or services they were interested in.

\subsection{Stimulus Materials and Manipulation}

The study stimuli were designed using four Facebook posts. Each post involved: e-WOM information content, number of likes received by the post, number of comments followed this post, and the name and a picture of the e-WOM source. The content and outlook were kept similar among the four posts. The only difference between them was in the source credibility and the recommendation rating. Manipulation of the source credibility was done by varying the e-WOM source. Aname of a known instructor was chosen as the high credible source, while the low credible source was manipulated by selecting a fictional name. A pretest showed that the two sources were significantly different in perceived credibility $\mathrm{p}<.01$. Recommendation rating indicates the number of Facebook users who like the post or comment on it. It is an indicator of the e-WOM popularity, and suggests social recommendation from other SNSs users. Following prior research $(\mathrm{Xu}, 2013)$, the manipulation for the social recommendation selected: 6 comments/likes for the low recommendation rating level, and 329 comments/likes for the high recommendation rating level. 
Guided by (Yang, 2012), a pretest was conducted to select the right product $(n=30)$. Among the surveyed products (mobile phones, cosmetics, digital cameras, tablets, etc.) tablets were found to have the minimum variance, and so, it was selected as the appropriate product for the research subject.

In result, this research investigated two factors with two level each; $2 \times 2$ study design. These factors are: source credibility (high and low), and recommendation rating (high and low).

\subsection{Procedures}

The experiment setting was a computer lab on campus. Participants were asked to see a screen-shot of an e-WOM review published in a Facebook group. They were then asked to complete an online survey about their perceptions of the e-WOM, e-WOM source credibility and their engagement and sharing behavioral intention toward it.

\subsection{Measurement}

Five constructs were studied in this study: source credibility; recommendation rating; engagement; e-WOM adoption; and sharing behavioral intention. All of the measurement used in this study were adopted from the literature. Well defined measurements were utilized for each one of the five constructs. The final measurement items and the source for each measurement are shown in appendix A. Responses were solicited using a 7-point Likert scale ranging from one (completely disagree) to seven (completely agree).

The survey items were pretested using a pilot study ( $n=30$ participants). The pretest focused on the message clarity, believability, and likability. Some survey items were revised based on the pretest results. After conducting the pretest, all respondents indicated that the survey questions are clearly understood, they also found it believable and likable. Responses from the pilot study were excluded from any further participation in the main study.

\subsection{Control Variables}

The following control variables were considered in this study: product familiarity, and gender. A T-test was used to check if there is a significant difference between participants who are familiar with the selected product and participants who are not. Another T-test was used to check if there is a significant difference between male and female participants. Results show no significant differences between familiar and unfamiliar participants, or between male and female participants.

\subsection{Common Method Bias Test}

To control for common method biases, Harman's single-factor test was used. The test was performed twice. At the beginning, it was used with all of the variables in the study, and then it was only used with the independent variables. Firstly, the first factor explains only $28.75 \%$ of the variance, when all variables were involved, which is not considered as a majority (Greene and Organ, 1973). Secondly, the first factor explains only $31.64 \%$ of the variance, when only the independent variables were involved; and this is not considered as a majority (Greene and Organ, 1973).

Table 1. Items Loading

\begin{tabular}{|c|c|c|c|c|c|}
\hline & $\begin{array}{l}\text { E-WOM } \\
\text { Adoption }\end{array}$ & Engagement & $\begin{array}{c}\text { Recommendation } \\
\text { Rating } \\
\end{array}$ & $\begin{array}{c}\text { Sharing } \\
\text { Behavior }\end{array}$ & $\begin{array}{c}\text { Source } \\
\text { Credibility }\end{array}$ \\
\hline Adop1 & 0.861 & & & & \\
\hline Adop2 & 0.847 & & & & \\
\hline Adop3 & 0.799 & & & & \\
\hline Adop4 & 0.788 & & & & \\
\hline Eng1 & & 0.861 & & & \\
\hline Eng2 & & 0.847 & & & \\
\hline Eng3 & & 0.776 & & & \\
\hline Eng4 & & 0.857 & & & \\
\hline Eng5 & & 0.844 & & & \\
\hline Rec.R1 & & & 0.829 & & \\
\hline Rec.R2 & & & 0.880 & & \\
\hline Rec.R3 & & & 0.832 & & \\
\hline SBI1 & & & & 0.820 & \\
\hline SBI2 & & & & 0.835 & \\
\hline SBI3 & & & & 0.827 & \\
\hline SC1 & & & & & 0.816 \\
\hline $\mathrm{SC} 2$ & & & & & 0.888 \\
\hline SC3 & & & & & 0.847 \\
\hline $\mathrm{SC} 4$ & & & & & 0.862 \\
\hline
\end{tabular}




\section{Results}

$55.6 \%$ of the subjects were female. The manipulations of both independent variables were successful. The known instructor and the fictional name were perceived significantly different by the participants, $\mathrm{p}<.01$. For recommendation rating, the low level (6 comments/likes) and the high level (329 comments/likes) were also perceived significantly different by the participants, $\mathrm{p}<.01$.

Partial Least Squares (PLS) Structural Equation Modeling (SEM) method was used in this research to evaluate the hypotheses model. Each item should load high on its corresponding construct, at least 0.7 (Hulland, 1999). The entire items' loading in this study exceeded this level as can be seen in table 1 .

To check for internal consistency, composite reliability scores were used, and exceeded 0.9 for all constructs, as shown in table 2, and thus, considered adequate (Hair et al, 1998). The Square Root of Average Variance Extracted (AVE) was used to test for discriminant validity; and found to be higher when comparing with the inter-construct correlations for all constructs as shown in table 2, consequently, discriminant validity was not a concern in this study.

Table 2. Internal consistency and discriminant validity

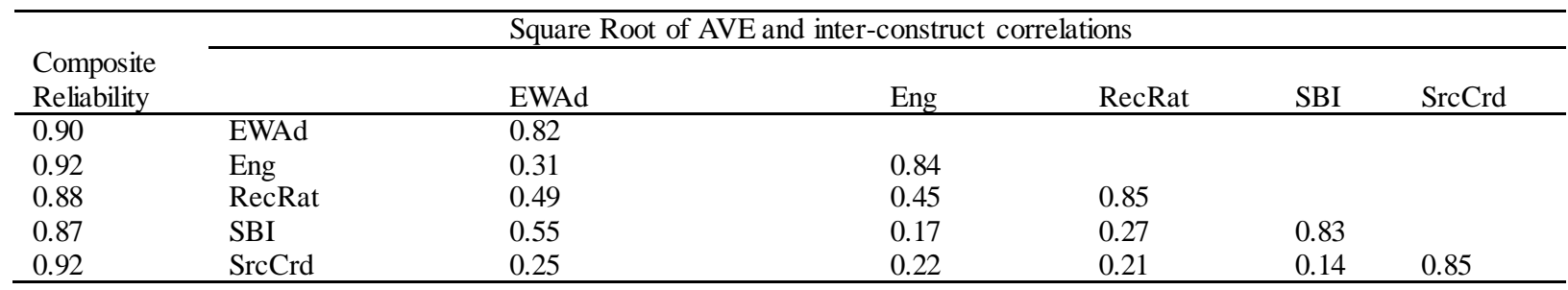

The study results are presented in figure 2. E-Wom Adoption had an R-Square of .523, engagement had an R-Square of .388, and sharing behavior intention had an R-Square of .298. This means that source credibility, recommendation rating, and engagement explain $52.3 \%$ of the variance in e-WOM adoption collectively. Source credibility and recommendation rating explain $38.8 \%$ of the variance in engagement collectively. E-WOM adoption explains $29.8 \%$ of the variance in sharing behavior intention (Agarwal \& Karahanna, 2000). Path coefficients were all significant as shown in Table 3. All six hypotheses are supported.

Table 3. Summary of hypotheses tests

\begin{tabular}{lccc}
\hline & Path Coefficient & T Statistics & P Values \\
\hline H6: EWAd ==> SBI & 0.546 & 8.774 & 0.000 \\
H5: Eng == EWAd & 0.306 & 3.839 & 0.000 \\
H4: RecRat ==> EWAd & 0.349 & 3.760 & 0.000 \\
H3: RecRat ==> Eng & 0.451 & 4.568 & 0.000 \\
H2: SrcCrd ==> EWAd & 0.184 & 2.065 & 0.039 \\
H1: SrcCrd ==> Eng & 0.223 & 2.125 & 0.034 \\
\hline
\end{tabular}

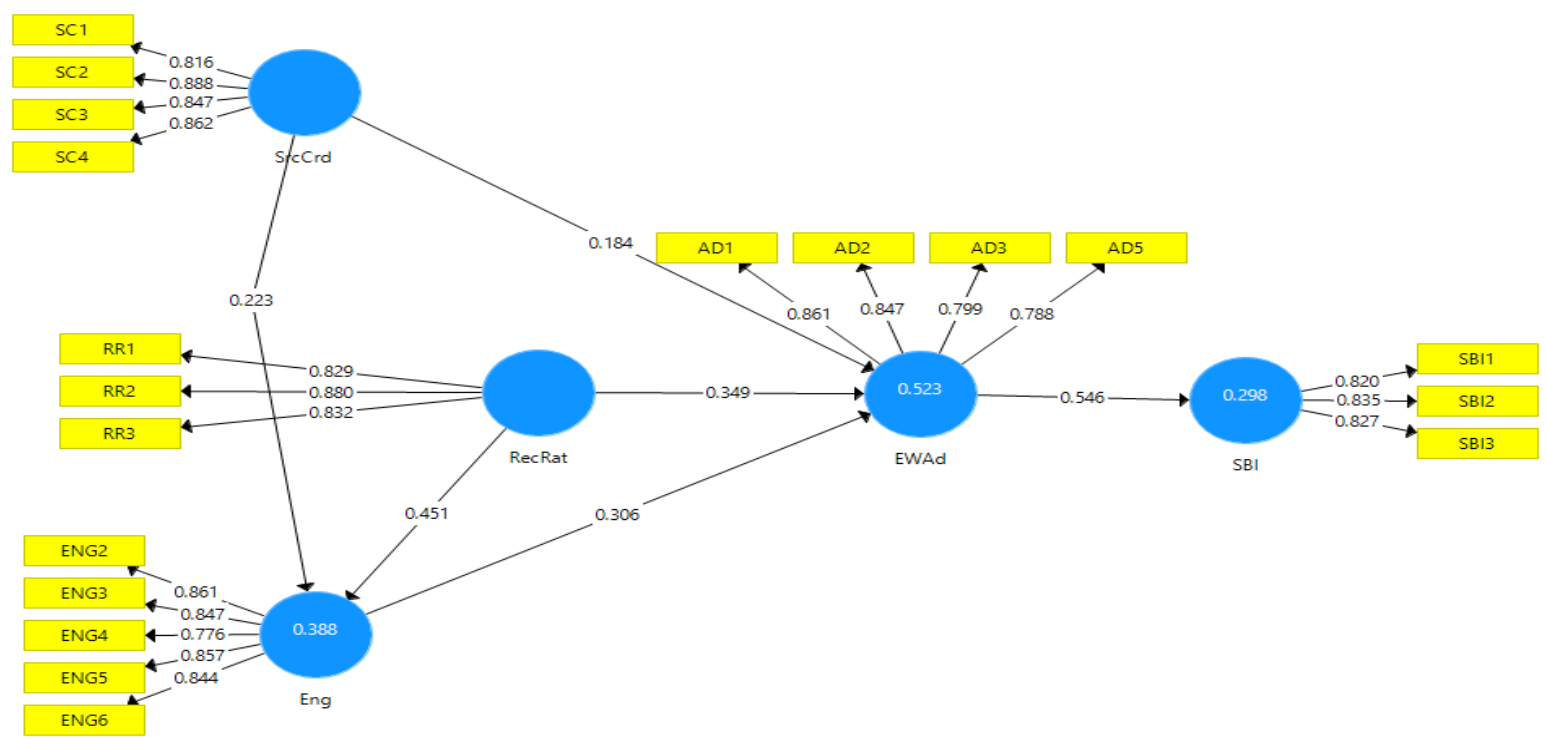

Figure 2. The measurement model 


\section{Discussion and Implications}

The peripheral route of the ELM has been utilized in this research to investigate the impact of factors not related to the message contents on its adoption, and hence, on its sharing by SNSs users. These factors are source credibility, recommendations rating, and SNSs users' engagement.

The results of this study yield deep insights. It indicates that there is a positive impact for source credibility and recommendations rating on SNSs users' engagement. Source credibility, recommendations rating and SNSs users' engagement have positive impacts on e-WOM adoption by SNSs users. There is also a positive impact for e-WOM adoption by SNSs users on their sharing behavior intention.

These research results are compatible with prior research, about the significance of source credibility, and its impact on the message credibility. This can be explained specifically by the ELM literature. ELM research argued that some factors not related to the message content, like source credibility, could influence the receiver perceptions of the message credibility. Meaning that, SNSs users believe online messages published by credibly perceived users. We extended this by studying its impact on the message adoption by SNSs users. When online users believe online messages and perceive it as credible, they adopt it, especially in their decision making process. This was supported by results of this research.

Recommendation rating was found to positively impact the message adoption. This result is consistent with prior research that found online message, endorsed by many other SNSs users, is considered as worthy of reading and hence, adopting (Xu, 2013). Johnson, Bichard, and Zhang, (2009) argued that the huge amount of information, available online, forces online users to be selective in their choices and decisions. We provide an evidence that information that have already been selected by many SNSs users will influence others to select it, believe it, and apply it in their decisions making processes. This can be explained more using Fiske and Taylor (1984) findings. They found that online users are lazy, in a way that make them resistant to spend any efforts in their selection of online information. They seek for an easy way that help them to decide what information worth reading, selecting, and adopting.

On SNSs, e-WOM adoption is an important factor to be investigated, because there are needs to know more about factors that make SNSs users adopt a message more than just believe it. Firms were found to be more interested in understanding how users of SNSs would be affected by their products' online reviews, and how they are convinced to act toward these products' reviews, rather than just believe it to be true and credible.

Results of this research showed that SNSs users, who felt engaged in SNSs groups, adopted published e-WOMs more than those who don't feel engaged in it. Engagement in SNSs groups brings more reasons for these group members to adopt e-WOM published in these groups. Research showed that engaged users spend more time online (Imlawi and Gregg, 2014) and hence, be affected more by online contents. Our results were consistent with prior research that found that users describe systems, which are perceived by them as engaging, as attractive systems (Mayes, 1992), and systems that encourage users to finish their activities (Laurel, 1991)

We also investigated the impact of message adoption by SNSs users on their sharing behavior intention. One of the main issues in e-WOM literature is spreading the word. SNSs have a huge spreading opportunity that is under investigated in literature. This research contributed to theory by investigating these factors. That is, when SNSs groups' members find message sources to be credible, when they feel engaged in these SNSs groups, as well as, when they recommended by other SNSs groups' members by receiving positive rating from them on these online messages, they adopt these online messages content for them first, and hence, share it with others on SNSs.

Investigating sharing behavior intention is one of the contributions of this research for practice as well. Firms should have a great interest in understanding how to spread the word about their products and services, especially when SNSs users do this with their friends, followers and other SNSs groups' members. Practitioners must be interested in results of this research because sharing e-WOM with more SNSs users reflects users' believe in e-WOM contents they get, and reflects users' adoption of e-WOM. Adoption of information about any product or service, and spreading and sharing of information about a product or a service are the best advertisement practitioners can offer for their products and services.

Results of this research provide strategies for firms to adjust their online activities in order to succeed in improving their customers' adopting of these firms' products and services' information, and improving those customers' sharing of information about these products and services. Specifically, firms can encourage their customers to spread e-WOM through their private SNSs platforms, because this source of e-WOM was proved by this research to be more influential on e-WOM readers than traditional sources. 
Another way can practitioners do to enhance their products and services information adoption and sharing by customers is by encouraging customers to highly rate products and services on SNSs by more likes, comments and sharing. Recommendation rating on SNSs is proved by this research to be more influential than rating on the firm's formal websites or even third party websites, because SNSs recommenders are friends on SNSs, and so are perceived as more credible sources.

\subsection{Limitations and Future Research}

This research studied: source credibility, recommendation rating and users' engagement in SNSs. However; there might be other factors that affect e-WOM adoption and its sharing behavior by online users (e.g. previous experiences). Future research could conduct an inductive approach to understand and list all of the different factors that might affect SNSs users' adoption and sharing of online information.

Recommendations rating have been manipulated using two levels of treatment, high (329) and low (6). There may be an optimum amount of recommendations rating that attract SNSs users. This study might be repeated with additional recommendation rating levels to help understand its effect on e-WOM adoption and sharing behavior.

The simulated Facebook groups used by this research may not sufficiently capture the impact of the factors studied in this research. Accordingly, future research is recommended to repeat the study with an experiment design, where SNSs users be engaged in a real SNSs groups.

External validity might be one of the limitations of this research, since the sample included students only. Using student as sampling units is overrepresented in information systems literature, mainly because of their availability; students are a readily available population on college campuses. However, they are not always representative of the general population. In this study, students were considered for the study sample, because we think that they are very similar in characteristics with the online customers, they are online customers anyway, because we asked a screening question to check if they used any SNSs to share e-WOM about products they are interested in. In addition, students shown to be main users on SNSs. However, targeting online users directly in their SNSs where they exchange e-WOM, about some products and services, might yield a better external validity, and so this would be recommended for future research.

Finally, e-WOM published by SNSs friends/followers were considered in this study. However, e-WOM published on SNSs by strangers (anonymous e-WOM) might have a different impact. Future research could study the difference between anonymous e-WOM and e-WOM from private social networks to understand more about the impact of each one of these e-WOM types on users' engagement and on other factors studied in this research.

\subsection{Conclusions}

SNSs have begun to be popular in different contexts and fields. Online information published in SNSs is increasingly influencing online users' decision-making process, and their attitude toward the content of this online information. Practitioners have started to recognize the outcomes when more e-WOMs are published by SNSs users who actually tried products and services mentioned in these e-WOM.

This research focused on using SNSs in message persuasiveness literature, by understanding how source credibility, recommendation rating and SNSs users' engagement in SNSs groups affect SNSs users' adoption of online information, as well as, online information sharing behavior intention.

\section{References}

Agarwal, R., \& Karahanna, E. (2000). Time flies when you're having fun: Cognitive absorption and beliefs about information technology usage. MIS quarterly, 665-694. https://doi.org/10.2307/3250951

Ayeh, J. K., Au, N., \& Law, R. (2013). “Do we believe in TripAdvisor?” Examining credibility perceptions and online travelers' attitude toward using user-generated content. Journal of Travel Research, 52(4), 437-452. https://doi.org/10.1177/0047287512475217

Berger, C. R., \& Calabrese, R. J. (1975). Some explorations in initial interaction and beyond: Toward a development theory of interpersonal communication. Human Communication Research, 1, 99-112. https://doi.org/10.1111/j.1468-2958.1975.tb00258.x

Cheung, C. M., \& Thadani, D. R. (2012). The impact of electronic word-of-mouth communication: A literature analysis and integrative model. Decision Support Systems, 54, 461-470. https://doi.org/10.1016/j.dss.2012.06.008 
Cheung, M. Y., Luo, C., Sia, C. L., \& Chen, H. (2009). Credibility of electronic word-of-mouth: Informational and normative determinants of on-line consumer recommendations. International Journal of Electronic Commerce, 13(4), 9-38. https://doi.org/10.2753/JEC1086-4415130402

Chevalier, J. A., \& Mayzlin, D., (2006). The effect of word of mouth on sales: Online book reviews. Journal of Marketing Research, 43(3), 345-354. https://doi.org/10.1509/jmkr.43.3.345

Chih, W., Wang, K., Hsu, L., \& Huang, S. (2013). Investigating electronic word-of-mouth effects on online discussion forums: The role of perceived positive electronic word-ofmouth review credibility. Cyberpsychology. Behavior and Social Networking, 16(9), 658-668. https://doi.org/10.1089/cyber.2012.0364

Fang, Y. H. (2014). Beyond the credibility of electronic word of mouth: Exploring eWOM adoption on social networking sites from affective and curiosity perspectives. International Journal of Electronic Commerce, 18(3), 67-102. https://doi.org/10.2753/JEC1086-4415180303

Fiske, S. T., \& Taylor, S. E. (1984). Social cognition reading. MA: Addison-Wesley.

Greene, C. N., \& Organ, D. W. (1973). An evaluation of causal models linking the received role with job satisfaction. Administrative Science Quarterly, 18, 95-103. https://doi.org/10.2307/2391931

Gretzel, U., \& Yoo, K. H. (2008). Use and impact of online travel reviews. Information and communication technologies in tourism, 35-46. https://doi.org/10.1007/978-3-211-77280-5_4

Hair, J. F., Anderson, R. E., Tatham, R. L., \& Black, W. C. (1998). Multivariate data analysis (Fifth Edition ed.). Englewood Cliffs, New Jersey: Printice-Hall Inc.

Harrison-Walker, L. J. (2001). The measurement of word-of-mouth communication and an investigation of service quality and customer commitment as potential antecedents. Journal of Service Research, 4(1), 60-75. https://doi.org/10.1177/109467050141006

Hassenzahl, M., \& Tractinsky, N. (2006). User experience: A research agenda. Behaviour and Information Technology, 25(2), 91-97. https://doi.org/10.1080/01449290500330331

Hu, Y., \& Sundar, S. S. (2010). Effects of online health sources on credibility and behavioral intentions. Communication Research, 37(1), 105-132. https://doi.org/10.1177/0093650209351512

Hulland, J. (1999). Use of Partial Least Squares (PLS) in Strategic Management Research: A Review of Four

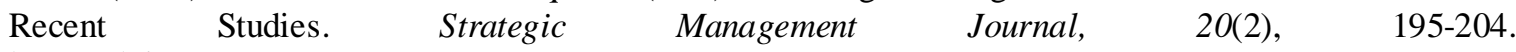
https://doi.org/10.1002/(SICI)1097-0266(199902)20:2<195::AID-SMJ13>3.0.CO;2-7

Imlawi, J., \& Gregg, D. (2014). Engagement in online social networks: The impact of self-disclosure and humor. International Journal of Human-Computer Interaction, 30(2), 106-125. https://doi.org/10.1080/10447318.2013.839901

Imlawi, J., Gregg, D., \& Karimi, J. (2015). Student engagement in course-based social networks: The impact of instructor credibility and use of communication. Computers \& Education, 88, 84-96. https://doi.org/10.1016/j.compedu.2015.04.015

Jacques, R., Preece, J., \& Carey, T. (1995). Engagement as a Design Concept for Hypermedia. Canadian Journal of Educational Communications, special issue on Multimedia Development, Spring, 49-59.

Johnson, T. J., \& Kaye, B. K. (2002). We believability: a path model examining how convenience and reliance predict online credibility. Journalism and Mass Communication Quarterly, 79, 865-879. https://doi.org/10.1177/107769900207900306

Laurel, B. (1991). Computers as theatre, Addison-Wesley, Reading, MA.

Lee, M., \& Youn, S. (2009). Electronic word of mouth: How eWOM platforms influence consumer product judgment. International Journal of Advertising, 28(3), 473-499. https://doi.org/10.2501/S0265048709200709

Lerman, K. (2007). Social information processing in news aggregation. IEEE Internet Computing, 11(6). https://doi.org/10.1109/MIC.2007.136

Li, J., \& Zhang, L. (2011) Online persuasion: How the written word drives WOM. Journal of Advertising Research, 51(1), 239-257. https://doi.org/10.2501/JAR-51-1-239-257

Li, X., \& Hitt, L. M., (2008). Self selection and information role of online product reviews. Information Systems Research, 19(4), 456-474. https://doi.org/10.1287/isre.1070.0154 
Luo, C., Luo, X. R., Schatzberg, L., \& Sia, C. L. (2013). Impact of Informational Factors on Online Recommendation Credibility: The Moderating Role of Source Credibility. Decision Support Systems, 56, 92-102. https://doi.org/10.1016/j.dss.2013.05.005

Malone, T. W., \& Lepper, M. R. (1987) Making learning fun: A taxonomy of intrinsic motivations for learning, In R.E. Snow, \& M.J. Farr (Eds.), Aptitude, learning and instruction, Erlbaum, Hillsdale, NJ.

Mayes, J. T. (1992). The 'M-Word': Multimedia Interfaces and Their Role in Interactive Learning Systems. In Multimedia Interface Design in Education, A. D. N. Edwards and S. Holland (eds.), Springer-Verlag. Berlin. pp. 1-22. https://doi.org/10.1007/978-3-642-58126-7_1

Morimoto, M., \& La Ferle, C. (2008). Examining the influence of culture on source credibility of Asian Americans and the mediating role of similarity. Journal of Current Issues and Research in Advertising, 30(1), 49-60. https://doi.org/10.1080/10641734.2008.10505237

Mudambi, S. M., \& Schuff, D. (2010) What makes a helpful online review? A study of customer reviews on Amazon. com. MIS Quarterly, 34(1), 185-200.

Nielsen. (2008). 81 percent of online holiday shoppers read online customer reviews, according to Nielsen Online. News release, Nielsen Company, New York.

O'Brien, H. L., \& Toms, E. G. (2010). The de velopment and evaluation of a survey to measure user engagement in ecommerce environments. Journal of the American Society for Information Science \& Technology, 61(1), 50-69. https://doi.org/10.1002/asi.21229

O'Brien, H. L. (2008). What is user engagement? A conceptual framework for defining user engagement with technology. Journal of the American Society for Information Science and Technology (1532-2882), 59(6), 938. https://doi.org/10.1002/asi.20801

Park, D. H., \& Lee, J. (2009). eWOM overload and its effect on consumer behavioral intention depending on consumer involvement. Electronic Commerce Research and Applications, 7(4), 386-398. https://doi.org/10.1016/j.elerap.2007.11.004

Pavlou, P., \& Dimoka, A. (2006). The nature and role of feedback text comments in online marketplaces: Implications for trust building, price premiums, and seller differentiation. Information Systems Research, 17(4), 392-414. https://doi.org/10.1287/isre.1060.0106

Petty, R., \& Cacioppo, J. T. (1986). Elaboration likelihood model. In L. Berkowitz (Ed.), Advances in experimental social psychology (pp.123-205). San Diego, CA: Academic Press.

Rieh, S. Y., \& Danielson, D. R. (2007). Credibility: A multidisciplinary framework. Annual review of information science and technology, 41(1), 307-364. https://doi.org/10.1002/aris.2007.1440410114

Salganik, M. J., Dodds, P. S., \& Watts, D. J. (2006). Experimental study of inequality and unpredictability in an artificial cultural market. Science, 311(5762), 854-856. https://doi.org/10.1126/science.1121066

Shoemaker, P. J., Johnson, P. R., Seo, H., \& Wang, X. (2010). Readers as gatekeepers of online news: Brazil, China, and the United States. Brazilian Journalism Research, 6, 55-77.

Sundar, S. S., \& Nass, C. (2001). Conceptualizing sources in online news. Journal of Communication, 51(1), 52-72. https://doi.org/10.1111/j.1460-2466.2001.tb02872.x

Sundar, S. S., Oeldorf-Hirsch, A., \& Xu, Q. (2008). The bandwagon effect of collaborative filtering technology. Proceedings of the 26th International Conference Extended Abstracts on Human Factors in Computing Systems (pp. 3453-3458). ACM. https://doi.org/10.1145/1358628.1358873

Sundar, S. S., Xu, Q., \& Oeldorf-Hirsch, A. (2009). Authority vs. peer: how interface cues influence users. Proceedings of the 27th International Conference Extended Abstracts on human factors in computing systems (pp. 4231-4236). ACM. https://doi.org/10.1145/1520340.1520645

Sussman, S. W., \& Siegal, W. S. (2003). Informational influence in organizations: an integrated approach to knowledge adoption. Information Systems Research; 14, 47-65. https://doi.org/10.1287/isre.14.1.47.14767

Tajfel, H., \& Turner, J. C. (1979). An integrative theory of intergroup conflict. In: Austin WG and Worchel S (eds) The Social Psychology of Intergroup Relations. Monterey, CA: Brooks-Cole, 33-47.

Thomas, J., Johnson, S. L. B., \& Weiwu, Z. (2009). Communication Communities or 'CyberGhettos? A Path Analysis Model Examining Factors that Explain Selective Exposure to Blogs. Journal of Computer-Mediated Communication, 15, 60-82. https://doi.org/10.1111/j.1083-6101.2009.01492.x 
Wathen, C. N., \& Burkell, J. (2002) Believe it or not: Factors influencing credibility on the Web. Journal of the American Society for Information Science and Technology, 53(2), 134-144. https://doi.org/10.1002/asi.10016

Webster, J., \& Ho, H. (1997). Audience engagement in multimedia presentations. The DATA BASE for Advances in Information Systems, 28(2), 63-77. https://doi.org/10.1145/264701.264706

Xu, Q. (2013). Social Recommendation, Source Credibility, and Recency Effects of News Cues in a Social Bookmarking Website. Mass Communication Quarterly, 90(4), 757-775.

Yang, T. (2012). The decision behavior of Facebook users. The Journal of Computer Information Systems, 52 (3), 50-59.

Zhang, W., \& Watts, S. (2004). Knowledge adoption in online communities of practice. Systemes d'Information et Management, $9(1), 81$.

\section{Appendix A}

\section{Measurements and Items}

Table A1 shows measurements and items used in the study.

Table A1. Measurements and Items

\begin{tabular}{|c|c|c|c|}
\hline Construct & & Items & Source \\
\hline Source credibility & ० & $\begin{array}{l}\text { Based on the rating system of the recommendation provider, this } \\
\text { provider is reputable } \\
\text { Based on the rating system of the recommendation provider, this } \\
\text { provider is highly rated by the forum members } \\
\text { Based on the rating system of the recommendation provider, this } \\
\text { provider is good } \\
\text { Based on the rating system of the recommendation provider, this } \\
\text { provider is trustworthy } \\
\text { Based on the rating system of the recommendation provider, this } \\
\text { provider is reliable }\end{array}$ & $\begin{array}{l}\text { Zhang, and Watts, } \\
\text { (2004) }\end{array}$ \\
\hline Recommendation rating & $\begin{array}{r}\text { Based o } \\
\text { review } \\
0 \\
0 \\
0\end{array}$ & $\begin{array}{l}\text { overall rating of other Facebook users regarding an e-WOM } \\
\text { g., likes and others' comments below the message): } \\
\text { The review was found to be favorable by other audiences. } \\
\text { The review is highly rated by other audiences. } \\
\text { The review was found to be approving by other audiences. }\end{array}$ & $\begin{array}{l}\text { Cheung, Luo, Sia, } \\
\text { and Chen, (2009) }\end{array}$ \\
\hline Engagement & $\begin{array}{l}0 \\
0 \\
0 \\
0 \\
0 \\
0\end{array}$ & $\begin{array}{l}\text { This Facebook group kept me totally absorbed in the browsing } \\
\text { This Facebook group held my attention } \\
\text { This Facebook group excited my curiosity } \\
\text { This Facebook group was fun } \\
\text { This Facebook group was intrinsically interesting } \\
\text { This Facebook group was engaging }\end{array}$ & $\begin{array}{l}\text { Webster } \\
\text { (1997) }\end{array}$ \\
\hline E-WOM Adoption & $\begin{array}{l}0 \\
\circ\end{array}$ & $\begin{array}{l}\text { To what extent do you agree with the review? } \\
\text { Information from the review contributed to my knowledge of } \\
\text { discussed product/service. } \\
\text { The review made it easier for me to make a purchase decision. } \\
\text { (e.g., purchase or not purchase). } \\
\text { The review motivated me to make a purchase action. } \\
\text { The review has enhanced my effectiveness in making a } \\
\text { purchase decision. }\end{array}$ & $\begin{array}{l}\text { Cheung, Luo, Sia, } \\
\text { and Chen, (2009) }\end{array}$ \\
\hline $\begin{array}{l}\text { Sharing } \\
\text { intention }\end{array}$ & $\begin{array}{l}0 \\
0 \\
0\end{array}$ & $\begin{array}{l}\text { How likely you will discuss the news with your friends } \\
\text { How likely you will share the news with your friends } \\
\text { How likely you will recommend the news to others }\end{array}$ & $\begin{array}{l}\mathrm{Hu} \text { and Sundar, } \\
(2010)\end{array}$ \\
\hline
\end{tabular}

\section{Copyrights}

Copyright for this article is retained by the author(s), with first publication rights granted to the journal.

This is an open-access article distributed under the terms and conditions of the Creative Commons Attribution license (http://creativecommons.org/licenses/by/4.0/). 